\title{
JJP Valeton jr as godsdienshistorikus
}

\author{
JA Loader
}

\begin{abstract}
J J P Valeton Jnr was one of the main founders of the theological current in nineteenth century Holland called 'the ethical theology'. Some of the most prominent members of this current were, like Valeton, Old Testament specialists. One of the main characteristics of the ethicals was their distinction between scientific knowledge and the knowledge of faith. This enabled them to adopt a critical approach to the Bible while at the same time remaining active in the service of the church. In this article it is shown how Valeton applied this principle in his work on the history of Israelite religion. An attempt is made to demonstrate how his insight was more penetrating than that of even the great Abraham Kuenen.
\end{abstract}

Josué Jean Philippe Valeton jr (1848-1912) was een van die vernaamste eksponente van die etiese teologie in Nederland. As sodanig het hy 'n belangrike rol gespeel in die bestryding van die sogenaamde moderne teologie na links en die gereformeerde ortodoksie na regs. Vanweë hierdie rol het hy gedurende sy lewe baie prominensie - instemmend sowel as afwysend - en erkenning ontvang. Ná sy dood is Valeton se werk egter grootliks verwaarloos. Dit het ten koste van die kerk en teologie gebeur. Sy belang vir die teologie in Suid-Afrika het te doen met die inhoud van sy denke, maar ook met die feit dat hy een van die grondleggers van 'n tradisie was wat veral via professore Berend Gemser (1890-1962) en Adrianus van Selms (1906-1984) alhier 'n nakomelingskap verkry het. Sover ek kan sien, het hierdie tradisie byna heeltemal van sy oorsprong vergeet. Dit spel natuurlik gevaar vir die voortgang en ontwikkeling daarvan. Omdat dit na my oordeel 'n groot skade sal wees as die positiewe impulse wat van die etiese tradisie uitgegaan het in Suid-Afrika (en veral in die Hervormde teologie) sou verdwyn, wil ek graag tot die herontdekking daarvan probeer bydra aan die hand van 'n enkele faset van Valeton se lewenswerk. Vanweë die feit dat Van Selms tot hierdie tradisie behoort het en in dieselfde idioom gedink het, sal dit wesenlik nie net aan Valenton herinner nie, maar ook aan die leermeester van so baie van ons wat nie altyd die historiese wortels van ons vorming besef nie.

Die etiese teologie van die negentiende eeu was nie van mening dat die belangrikste element van die godsdiens sedelik ( $\mathrm{vgl} \mathrm{ethica)} \mathrm{is} \mathrm{nie,}$ 
maar dat die wese (ethos) van die waarheid alleen in ' $n$ ontmoeting ervaar kan word en nie in proposisies uitdrukbaar is nie. Hierdie opvatting het dit vir Valeton en sy geesgenote moontlik gemaak om krities om te gaan met die begrippe of proposisies oor God wat in die Bybel voorkom en tegelyk die moderniste se afwysing van alle openbaring te opponeer.

Dit is merkwaardig dat hierdie teologiese debat grootliks deur $\mathrm{Ou}$ Testamentici gevoer is. Die meer prominente etici rondom die eeu-wisseling was Ou-Testamentici, en onder hulle was Valeton ongetwyfeld die kleurvolste leier. Hy het uit 'n geslag van Franse refugiés gestam en sy liefde vir die Ou Testament by sy vader, J J P Valeton sr, hoogleraar in Ou Testament te Groningen, geleer. Ná Valeton jr se promosie in Utrecht en vyf jaar in die bediening het hy op 8 Desember 1877 professor aan sy alma mater geword. Hy was 'n gewilde dosent, maar ook iemand 'die, nerveus en vaak overmoe, zich vrienden én vijanden maakte' (Gunning 1940: 72). Hy het altyd kerklik betrokke gebly en met ywer en soms heftig aan die kerklike en teologiese debatte van sy tyd deelgeneem.

Valeton was 'n Ou-Testamentikus van nering, maar sy lewenswerk omvat so baie fasette dat ons net aan een daarvan aandag sal gee. Naas talle geskrifte oor die wese en taak van die etiese teologie en die veronderstelling en gestalte van 'n kritiese teologie het hy ook uitgebreide studies op godsdienshistoriese en eksegetiese gebied gepubliseer, en daarbenewens bekendheid verwerf met 'n massa populêre en stigtelike werke (Loader 1984b: 12, 224-226). (Afgesien van inhoudelike oorwegings is die formele ooreenkoms hiervan met Van Selms se massiewe volume geskrifte op sistematies-teologiese, godsdienshistoriese, eksegetiese, populêre en stigtelike gebied [Loader 1985a] te opsigtelik om mis te kyk.)

Valeton kon sy godsdienshistoriese arbeid ontwikkel op die basis van die etiese teologie, naamlik dat die waarheid nie proposisioneel is nie. God openbaar dus nie stẹllings en begrippe en dogmas nie, maar Hy maak Homself bekend. Nadat mense met Hom self in ontmoeting gekom het, kan hulle nie anders daaroor praat as in proposisionele vorm nie. Dus is die menslike getuienis oor die openbaring nie gelyk aan die openbaring self nie en daarom oop vir kritiek. Daarom is ook die Israeliete se uitdrukking van hul ontmoeting met God oop vir 'n kritiese, dit wil sê wetenskaplike, studie. Vandaar die moontlikheid om voluit aan die godsdienshistoriese analise daarvan deel te neem sonder om in die eensydigheid van die moderniste te verval. 
Die aard van die teologie het 'n prominente debatspunt geword toe die Nederlandse 'Wet op het Hooger Onderwijs' in 1877 in werking getree het. Hierin is die identiteit tussen teologie en godsdienswetenskap as prinsipe neergelê. Daarteenoor het Valeton gestel dat dit in die teologie gaan om 'het absolute' (Valeton 1898: 28). Voordat daar egter tot so 'n teologiese evaluering gekom kan word, moet die religieuse gegewens waarop die beoordeling gebaseer moet word, eers versamel en gerangskik word. En dit is nie anders as met 'n godsdienswetenskaplike metode moontlik nie. Hiervolgens maak Valeton dus ' $n$ onderskeid tussen twee bewegings in die werk van die teoloog. Die eerste is ' $n$ wetenskaplike versameling, ordening en interpretasie van godsdienstige fenomene (godsdienswetenskap), en die tweede is die religieuse 'waardeering' of evaluasie daarvan (teologie). Hy self noem die twee aspekte 'een zuiver wetenschappelijke' en 'een godsdienstig-theologische' (Valeton 1895: 10). Ten opsigte van eersgenoemde is kennis die doel en metode die weg, terwyl die ondersoeker nooit kan 'verder gaan dan waartoe de wetenschappelijk bruikbare gegevens in staat stellen' (Valeton 1895: 11). Die tweede beweging word egter nie hierdeur nie, maar deur geloof beheers en word daar waarde-oordele uitgespreek (vgl Loader 1985b).

Op hierdie wyse het Valeton 'n duidelike onderskeid, maar ook 'n onontbeerlike verbondenheid tussen godsdienswetenskap en geloof aangemerk. Dit is daarom ook goed verstaanbaar dat so baie van sy geskrifte oor die Ou Testament op die gebied van die godsdienswetenskap lê. Een van sy grootste verdienstes is dat hy die twee soorte kennis wat ten grondslag lê aan respektiewelik die godsdienswetenskap en die teologie, naamlik wetenskaplike en geloofskennis, duidelik onderskei het. Dit is sy bydrae tot die antwoord op die sentrale vraag van die negentiende-eeuse teologie, die probleem van die verhouding tussen rede en geloof.

Valeton se duidelike onderskeid tussen die twee aspekte, hul doel en hul metode, het gepaard gegaan met 'n verdere gesonde insig. Die twee is nie alleen verbonde in die sin dat die godsdienswetenskaplike aspek die gegewens vir die teologiese moet versamel nie, maar ook in 'n nog dieper liggende sin. Die wetenskaplike of 'analytisch-synthetische' en die evaluerende kante kan nie waterdig van mekaar geskei word nie. Die wetenskaplike kant kan ook beïnloed word deur die subjektiewe instelling van die ondersoeker sodat die invloed van die persoonlikheid nooit uitgesluit kan word nie 'en daarmee dus ook niet de invloed van het geloof'. Omgekeerd kan vooruitgang in wetenskaplike kennis 
ook geloofsinsigte beïnvloed (Valeton 1898: 28). Daar moet dus nie 'n eenrigting-verkeer van die godsdienswetenskap na die teologie bedryf word nie, maar eerder rekening gehou word met ' $n$ wisselwerking tussen die twee. Hierdie resiproke verhouding is so eng dat Valeton nie wil weet van 'n teologie wat die godsdienswetenskap ontbeer nie en selfs nie van 'n teologie wat net bereid is om die godsdienswetenskap alleen maar langs hom toe te laat nie.

In hierdie opsig het Valeton getoon dat hy 'n dieper insig as die moderniste links van hom en die ortodoksie aan die regterkant gehad het. By beide hierdie groepe het projeksionisme hoogty gevier - die perspektief van die modernistiese of ortodokse groepe is telkens geprojekteer tot die alleengeldige. Valeton se kritiek op vooraanstaande moderniste soos Abraham Kuenen, Hendrik Oort en C P Tiele, naamlik dat hulle net so tendensieus soos die ortodoksie in diens van 'n bepaalde religieuse oortuiging getree het (Valeton 1879: 208-211), kon nooit deur hulle weerlê word nie omdat hulle nie ingesien het dat die oortuiging van die onversoenbaarheid van openbaringsgeloof en die historiese kritiek 'n godsdienstige oordeel is nie. Valeton het egter nie 'n vrypas vir ongekontroleerde subjektiwisme gegee nie. Hoewel daar geen absolute objektiwiteit moontlik is nie, moet nogtans daarna gestreef word om die invloed van veronderstellings, basiese oortuigings en geloofsperspektief te beperk. Haalbare objektiwiteit beteken hiervolgens om bewus te word van die ondersoeker se vooronderstellings. Hiervoor het die etiese opvatting voorsiening gemaak, maar nie die positiwistiese objektiwiteitsidee van die moderniste of die ortodokse reaksie daarop waardeur vooronderstellings toegelaat is om amok te maak nie.

Valeton het die wetenskaplike en evaluerende aspekte so eng met mekaar verbind dat hy hulle in 'n enkele teorie opgeneem het. Hy het dit egter nie in 'n afsonderlike publikasie uitgewerk en geformuleer nie, maar dit ontwikkel in talryke geskrifte oor spesifieke temas. Telkens vind ons in hierdie geskrifte die twee kante 'theologie/godsdienstwetenschap', 'Godskennis/kennis' of 'geloof/wetenschap'. Hoewel dit in sy werke oor openbaring en inspirasie sowel as in sy literêrkritiese studies van die Ou Testament na vore kom, sal ons hier aandag gee aan sy vernaamste godsdienshistoriese werke. Dit spreek vanself dat daar moeilik prinsipieel tussen sy histories-kritiese ondersoek van literère dokumente en sy godsdienshistoriese werke geskei kan word veral in die lig van sy eie opvattinge waaraan ons so pas aandag gegee het - maar prakties is dit wel moontlik. 
Valeton het twee indringende studies oor die geskiedenis van Israel se godsdiens geskryf (Valeton 1881 en 1897). Hierin kan ons hom as historikus op sy beste sien, ook die mate waarin hy die groot Abraham Kuenen oortref het. Kuenen, die onbetwiste leier van die modernistiese Ou-Testamentici, het gedurende 1869 en 1870 'n groot tweebandige geskiedenis van die Israelitiese godsdiens gepubliseer. Dit het die klassieke beskrywing van die evolusionistiese opvatting van die godsdiensontwikkeling in Israel geword. Kuenen het by ' $n$ aantal agsteeeuse profete begin omdat hy geoordeel het dat die bronne hier vir die eerste keer betroubaar word. Vervolgens het hy terug en vorentoe geredeneer en gestel dat Israel vroeër 'n politeistiese of henoteïstiese godsdiens beoefen het. Hy het ook sy revolusionêre teorie oor die Pbron as 'n na-eksiliese geskrif hier ingebou (vgl Loader 1984a: 13-17). Die hele konstruksie werk met die konsep van 'n evolusionêre ontwikkeling van laag na hoog en met die veronderstelling dat alle openbaring in die godsdiens ontken moet word. Hiermee het Kuenen in moeilike vaarwater beland (vgl Loader 1984a: 19-22), en is deur Valeton (1881) met 'n spervuur van logiese argumente aangeval (vgl Loader 1984b: $46-47)$ :

1. Kuenen veronderstel bloot dat alle godsdiens 'met fetichisme begint, zich later tot polytheïsme ontwikkelt en zoo eerst tot monotheïsme opklimt' (Kuenen 1869: 224), terwyl dit nie 'n bewysbare sekerheid is nie omdat dit nie feitelik in tekste blyk nie.

2. Indien daar 'n liniêre ontwikkeling was wat in 'n geestelike monoteissme uitgemond het, dan moet hierdie geestelike element van die eindpunt 'ook in de kiem aanwezig geweest zijn' (Valeton 1881: 106).

3. Kuenen redeneer homself vas deur te stel (Kuenen 1869: 369) dat Jahwe vroeër alleen in mag en verhewenheid van die ander gode verskil het, maar dat later 'voor het verschil in trap een soortelijk onderscheid was in de plaats getreden'. Hieruit volg dat die latere Jahwe van die vroeëre in soortelike opsig verskil het en nie alleen in ontwikkelingstadium nie. Dus kan daar van liniêre ontwikkeling geen sprake wees nie.

4. 'n Verdere konsekwensie hiervan is: ò daar is geen samehang tussen die profete met hul monoteïsme en oud-Israel nie - dan kan Kuenen die vraag na die herkoms van die soortelik verskillende Jahwe nie beantwoord nie - of, as hy aan die samehang wil vashou,

5. dan verval hy in die dilemma dat hy moet kies tussen die konsekwensie dat daar geen monoteïsme in die agste eeu was nie en dié 
dat monoteïsme reeds van die begin daar was. Dus verval Kuenen se hele tese en daarmee sy hele beeld van die Israelitiese godsdiensgeskiedenis in elk geval.

6. As die profetiese verwysings na natuurelemente slegs beeldspraak is (so Kuenen 1869: 221), dan bewys dit nie dat die profete nie 'n natuurgodsdiens nie, maar'n godsdiens wat daaruit ontwikkel het, beoefen het nie. Dit is 'n sirkelargument wat alleen berus op die uitgangsveronderstelling dat 'n vroeëre reële opvatting van natuurelemente later in 'n simboliese opvatting ontwikkel het.

7. Kuenen se verwysing na reële godsdienselemente, soos die ark, stierdiens, menseoffers en die besnydenis (Kuenen 1869: 231-239), bewys nie ' $n$ ontwikkeling binne Israel van laag na hoog nie, want dit hou nie rekening daarmee dat Israel soms sulke dinge kon ontleen het aan ander godsdienste nie. Dus hoef die natuurgebonde godsdienstipe nie inherent deel te wees van 'n Israelitiese ontwikkelingsproses nie.

Hiermee het Valeton die onhoudbaarheid van die basis waarop Kuenen se hele grootse godsdiensgeskiedenis gestaan het, aangetoon. Hy het dit teen evolusionisme gehad, nie teen die idee van ontwikkeling as sodanig nie (Valeton 1881: 12, 108, 109). Ontwikkeling beteken vir hom nie noodwendige liniêre selfontplooiing nie, maar verandering wat voor- sowel as agteruitgang kan insluit. Hierdeur het hy dit moontlik gemaak vir later Ou-Testamentici om die naïewe voorstelling van die Israelitiese godsdiensgeskiedenis op beter gronde vaarwel toe te roep as wat Kuenen gebied het. Op hierdie punt kan ons 'n goeie illustrasie sien van die belang van die etiese benadering oor die algemeen. Die tradisionele fundamentalistiese beskouing van die godsdiens van Israel (om 'n hedendaagse uitdrukking te gebruik) kon nie meer wal gooi teen die vloedgolf van oortuigende resultate van die historiese kritiek nie, maar die alternatief van die evolusioniste was vir talle mense ewe onaanvaarbaar. In hierdie situasie het Valeton nie bemiddel in dié sin dat hy elemente uit twee onversoenbare uiterstes probeer verenig het nie, maar ' $n$ volledige derde opsie uitgewerk. Dit was dus nie nodig om in die onwetenskaplikheid van die ortodoksie te bly sit of in die eksesse van die modernisme te verval nie. Hoewel Valeton nie daarin geslaag het om die moderniste te oortuig nie, het hy die etiese teoloë in hul opvatting versterk. Sy geskrifte is nie naastenby so omvangryk as Kuenen s'n nie en bevat ook nie so 'n rigtingbepalende tese soos dié van die Priesterlike Dokument in Kuenen se boek nie, maar ons moet vandag oordeel dat hy ten opsigte van insig in die Israelitiese godsdiensgeskiedenis, sy oog vir die swakheid van die 
evolusionistiese opvatting en sy konsekwente beredenering daarvan Kuenen se meerdere was.

Tot hiertoe het ons aandag gegee aan die reaksionêre of negatiewe element in Valeton se werk van 1881, sy dit dan 'n negatiewe aspek waaruit veel positiefs gespruit het.* Die studie dra egter ook 'n eie karakter wat nie noodwendig bepaal word deur die verhouding daarvan tot Kuenen se werk nie. Die werk is eerder 'n tipering van die Israelitiese godsdiens as ' $n$ kronologiese beskrywing daarvan. Uiteraard hou Valeton rekening met die historiese omlysting van die Israelitiese godsdiens, maar dit moet eerder beskou word as die voorbereiding vir'n eintlike beskrywing van die godsdiensgeskiedenis.

Valeton betoog dat Israel aanvanklik wel politeisme geken het. Vanaf die agste eeu begin die monoteïsme egter die oorhand kry en sedert die ballingskap het Israel as volk monoteïste geword. Hierdie ontwikkeling het nie plaasgevind as gevolg van rasionele nadenke oor die bestaan van een of meerdere gode nie, maar as gevolg van 'n magtige religieuse indruk. As die ontwikkeling aan so ' $n$ indruk toegeskryf moet word, dan moet hierdie impuls by die ontstaan van die Jahwisme gesoek word. In die loop van die geskiedenis het Israel toegewings aan hul politeïstiese omgewing gedoen, maar uiteindelik het die monoteïsme die oorhand gekry vanweë die nasionalistiese teokrasie se behoefte aan 'n 'eie' God. Hierdie opvatting verklaar waarom Valeton dieselfde opvatting oor die teenwoordigheid van politeïsme in die beginstadia en later kon huldig as wat vandag gewoonlik die geval is, maar in teenstelling tot hedendaagse tendense, tog meer klem op die eenheid as die pluraliteit gelê het.

Soos verwag kan word, was die feit dat die Israeliete Semiete was vir Valeton belangrik. Ons kan die betekenis hiervan waarneem in sy opvattings oor die godsbeeld van die Israeliete. Dit is gebou op die konsep van mag, maar die idee van 'n heersersgod lei tot dié van 'n volksgod. Dit veroorsaak weer 'n sedelike karakter in die godsdiens omdat ' $n$ heersersgod gehoorsaamheid eis en daarom word die godsdiens gekenmerk deur 'n stemming van ontsag vir die verhewe god. Vanweë hierdie tipies Semitiese godsvoorstelling, waarmee volgens Valeton die 'simboliese' aard van hul gode verband hou, kon die monoteïsme later deurbreek, al is die bestaan van meerdere gode aanvanklik nie ontken nie.

- Vgl die treffende opmerking van Kallay Kálmán in die Dunéntuli Protestans Lap (Transdonouse Protestanteblad') van 11 Februarie 1912: ' . . ook waar hy (d i Valeton) moes afbreek, het hy opgebou'. 
Soos elke godsdiens het ook die Israelitiese religie drie basiese aspekte: 'n eie dogmatiese sisteem, 'n konserwatief-geneigde kultus, en 'n sedelike invloed wat moeilik beskryfbaar is. Al drie hierdie aspekte kom uit die religieuse bewussyn van die mens, en dié word weer bepaal deur die verhouding tot God waarvan die mens hom bewus voel. Hier kan ons duidelik die grondliggende kenmerk van die etiese benadering sien: aan die een kant 'n ontmoeting met God, en aan die ander kant die vormgewing daarvan in menslike religieuse kategorieë. Dit alles beteken volgens Valeton dat die uitwendige religieuse vorme nie die objek van openbaring kan wees nie - dit sou sowel die psigologiese as die ontologiese grond van die godsdiens ontken. Was dit anders, sou ons gedwing word om aan te neem dat die menslike bewussyn oorspronklik ateïsties was. Daar is derhalwe geen 'absolute inspiratie' nie, en die godsdiens moet ten opsigte van al drie sy aspekte beskou word as 'n produk van die menslike gees (Valeton 1881: 9-12).

Die veranderinge wat in die godsdiens intree, moet nie aan ' $n$ immanente ontwikkeling toegeskryf word nie, maar aan ervaringe en indrukke wat uit sy omgewing op die menslike gees inwerk. Die veranderinge wat in die geskiedenis van die Israelitiese godsdiens ingetree het, kan dus nie beskou word as die resultaat van wat God aan Israel meegedeel het nie (wat 'inspirasie' sou heet). Daarmee het Valeton nog 'n belangrike element in die godsdienswetenskap van sy tyd aangeraak, naamlik die eerste aanduidings van godsdienssosiologiese en godsdienspsigologiese belangstelling. Hy het dit nie verder uitgewerk nie, maar wel 'n antisipasie van latere ontwikkelinge op die vakgebied tot stand gebring.

Die belang van die ervaring van indrukke vir sowel die ontstaan van die godsdiens as die ontwikkeling daarvan bring volgens Valeton ook implikasies vir die teologie mee. Daar word naamlik dikwels ten onregte deur teoloë gepoog om 'verkeerde' en 'aanstootlike' dinge in die godsdiens weg te verklaar en te harmoniseer met wat vir hulle aanvaarbaar is. Hiermee het Valeton ' $n$ baie belangrike saak aangeraak, iets wat selfs vandag nog dikwels nie voldoende ingesien word nie. As die Israelitiese godsdiens ' $n$ openbaringskarakter dra, dan beteken dit nie dat die godsdiens self geopenbaar is nie. Godsdienshistories gesproke was Israel hulle bewus daarvan dat God Hom aan hulle geopenbaar het. Die uitdrukking wat hulle hieraan gegee het, verteenwoordig die openbaringskarakter van die Jahwisme, maar dit is nog Israel se uitdrukking van die openbaringsbewussyn, nie die openbaring self nie. As God Homself aan Israel bekendgemaak het (soos Israel geglo het), dan het Hy nie 'n ding nie, maar sy Persoon geopenbaar. Waar hierdie 
basiese indruk vandaan kom, kan die wetenskap nie sê nie, maar die teologie kan ook nie die wetenskap sy plig ontneem om die menslike verskynsel wat daarop volg, te ontleed nie (vgl Valeton 1881: 13-15). Openbaring is die versterking van indrukke wat mense van nature van God het. Dit herstel 'n gebroke verhouding en gaan offers vooraf (Valeton 1881: 20-21). Hierdie opvatting het eweneens teologiese implikasies, wat egter nie in 'n godsdienswetenskaplike werk ontwikkel kan word nie. Wat wel bygevoeg kan word, soos Valeton inderdaad doen, is om die rol van inspirasie in so 'n godsdiens te tipeer. Die openbaring van God kom in allerlei manifestasies tot stand. Inspirasie is dan die werking van God in die mens sodat hy die manifestasies as die werk van God kan herken. Een gegewenheid kan egter herhaaldelik deur verskillende mense op verskillende maniere geïnterpreteer word. So is dit gewoonlik ' $n$ individuele indruk wat later deur die krag van persoonlike oortuigings ontwikkel tot 'n algemene oortuiging van meerdere mense. Die godsdiens groei dus deur die tyd heen en het nie bloot deur die openbaring van 'feite' uit die lug geval nie. Die opmerklike in hierdie hele uiteensetting is dat Valeton geen identifikasie maak tussen openbaring en die Bybel nie. Daarom is die Bybel oop vir kritiese, dit is wetenskaplike, studie.

Die deurbraak van die profetiese monoteïsme het volgens Valeton eers werklik sedert die ballingskap plaasgevind. Hierdie onderwerp hou ook verband met sy siening van die openbaring. Hy meen dat erkenning van meerdere gode nie afgelei kan word uit die feit dat geen ontkenning van hulle bestaan by die voor-eksiliese profete te vind is nie (Valeton 1881: 87). Ander gode kom nie in die gedrang nie omdat die profete se blik op Israel gerig is. Israel se relasie met slegs een God het veroorsaak dat Jahwe die ander gode laat verbleek het. Dit veronderstel 'n selfopenbaring van God wat ' $n$ eenheid en 'middelpunt' aan al die verspreide indrukke gee (Valeton 1881: 94-95). Vandag sou daar waarskynlik geoordeel word dat die 'middelpunt' waarvan Valeton praat, miskien nog vir die dokumente van die huidige Ou Testament kan geld maar nie vir die historiese Israel nie, en dat die diversiteit waarvan Valeton wel bewus was nie ernstig genoeg geneem word nie. Dit sou egter nog nie afbreuk doen aan die openbaringskarakter van die Israeliete se godsdiens wat volgens Valeton veronderstel word deur die noue betrekking wat hulle met Jahwe gevoel het nie. Dit beteken ook dat die Jahwisme, wat teruggevoer moet word tot die tyd van die volk se ontstaan, in beginsel reeds van die begin af ' $n$ monoteïstiese godsdiens was. 
Valeton se hele tipering van die Israelitiese godsdiens word beheers deur sy etiese benadering. Die motief van die relasie tussen God en mens is bepalend vir sy behandeling van die openbaringsidee, van die mono- en henoteïsme, die sedelike karakter en die ontstaan van die godsdiens. Sy klem op godsdiens as die resultaat van 'n ervaring van die numineuse het dit vir hom moontlik gemaak om 'n konsistente beeld te bied sonder die innerlike teensprake waarin Kuenen verval het, om ontwikkelinge as eb en vloed te beskryf, en boonop die moontlikheid vir teologiese aansluiting by die godsdienswetenskap oop te hou.

Die tweede belangrike bydrae van Valeton tot die beskrywing van die godsdiens van die Israeliete het gedurende 1897 in P D Chantepie de la Saussaye se bekende handboek van die godsdiensgeskiedenis verskyn. Anders as die werk van 1881 is hierdie een nie 'n tipering van die godsdiens aan die hand van 'n aantal temas nie, maar 'n beskrywing van die geskiedenis daarvan aan die hand van die vier periodes. Ten spyte van Valeton se begrip vir die diversiteit van die religie van die Israeliete en die verskille in verskillende tye, bou hy voort op die idee van die wesenlike eenheid van die Israelitiese godsdiens.

Wat Valeton die 'hoofdogma' van die Jahwisme noem, is die opvatting 'Jahve ist der Gott Israel's, Israel das Volk Jahve's' (Valeton 1897: 247). Sy beskrywing van die godsdiensgeskiedenis sentreer om hierdie middelpunt. Hiermee het hy nog 'n verskynsel geantisipeer wat later aan die orde van die dag sou tree, naamlik die opvatting van ' $n$ middelpunt van die Ou Testament waaromheen soveel teologieë (eerder as godsdiensgeskiedenisse) gebou sou word. Volgens Valeton word die eenheid van die verskillende kante van die godsdienstige lewe van Israel vereis deur die 'formell einheitliche Gottesbegriff' wat deur die naam jhwh uitgedruk word.

Voordat hy met die eintlik beskrywing van die Israelitiese godsdiensgeskiedenis begin, toon Valeton dat hy ook in die evaluering van die bronne daarvoor die meerdere van die meeste moderniste van sy tyd was. Hy het aanvaar dat die meeste bronne vir die ontstaansgeskiedenis van Israel (en dus ook van sy godsdiens) sages is, maar nie - soos die gangbare liberale opinie dit wou hê - daaruit afgelei dat die aartsvaders daarom onhistories was nie (Valeton 1897: 251-252). Ten opsigte van hierdie periode het hy die 'Israelitiese' godsdiens as 'n stamgodsdiens beskou en ' $n$ eng verband tussen die sosiale lewe en die religie aanvaar. Volgens hom het die besnydenis en die pasga waarskynlik hul oorsprong in hierdie tyd gehad. 
Sonder om dit in besonderhede uit te werk (soos Albrecht Alt later sou doen), het Valeton wel 'n voortgang tussen die God van die vaders en die latere Jahwisme gesien. Herinneringe aan die God van die vaders het die basis geword waarop die Jahwisme vanaf die tyd van Moses uitgebou kon word. Die nie-evolusionistiese ontwikkelingskonsep waarmee Valeton gewerk het, kan goed gesien word in sy opvatting dat die Jahwisme ' $n$ innerlike lewenskrag gehad het wat hom in staat gestel het om die gevaar te oorleef wat die ontwikkeling van 'n nomadekultuur na 'n akkerboukultuur ingehou het. Die Jahwisme kon saam ontwikkel sonder om verstrik te raak in die remminge van assosiasie met ' $n$ enkele kultuurvorm (Valeton 1897: 268-272).

Die eerste voor-eksiliese periode word afgesluit met die tyd tussen die intog in Kanaän en die optrede van Jehu, toe dit gegaan het om die handhawing van die Jahwisme. Die kultuurstryd tussen stad en platteland sowel as die rykskeuring hou verband met die teenstand teen die uitdrukking van die Jahwisme, wat nou die enigste godsdiens van Israel geword het, in die Salomoniese tempel en kultus. 'n Interessante ironie lê in die feit dat restouratiewe anti-dinastieke elemente in die Noordryk (dus konserwatiewe groeperinge) na die ou Kanaänitiese stierkultus gegryp het as teenvoeter vir die Jerusalemse godsdiens. So het daar 'n verbinding gekom tussen nasionalistiese eksklusivisme en 'n sinkretistiese godsdiens.

Die tweede voor-eksiliese periode word deur Jehu ingelui. Dit is volgens Valeton die tyd van die gronddogma. Nou lê die klem op Israel wat die wil van Jahwe moet doen. Hier kom die sogenaamde etiese monoteisme tot ontwikkeling, soos veral gesien kan word in die verkondiging van Jahwe as morele persoon deur die agste-eeuse profete. Die vyande van Israel word instrumente in die hand van Jahwe teen sy ongehoorsame volk, en te midde hiervan kom die messiaanse verwagting eerste by Amos voor. Valeton aanvaar ook dat die Godsbegrip in Israel nie altyd dieselfde was nie deurdat hy 'n verdieping daarin bespeur wanneer Jesaja se voorstelling van die heiligheid van Jahwe sy intrede doen. Nou kom die idee van 'n geestelike ryk in die plek van die vroeëre klem op politieke mag. Die konsekwensie van die etiesontwikkelde gronddogma is dat ondergang vir Israel wag as hy ongehoorsaam bly.

'n Interessante gesigspunt wat vandag weer onafhanklik van Valeton begin aandag kry, word in hierdie verband deur hom geopen. Hy meen dat die profetiese party 'n sterk invloed in die Suidryk uitgeoefen het en dat dit die effek van 'n ferment gehad het. Dit het tot gevolg gehad 
dat hul gedagtes in hooftrekke vir die praktiese lewe neergelê moes word. Die kodifisering hiervan is onderneem in die deuteronomiese wetgewing. Die profete het dus nie soseer in die gees van Deuteronimium opgetree nie as wat Deuteronomium omgekeerd in die profetiese gees ontstaan het (Valeton 1897: 288-289). Volgens Valeton wil die deuteronomiese wetgewing die eenheid van die Jahwisme tot uitdrukking bring; vandaar die klem op die sentralisasie van kultus. Nog 'n skerpsinnige historiese waarneming van Valeton is dat hierdie religieuse opset die begin van die krisis in die vergeldingsleer verteenwoordig. Dié leer staan sentraal in die deuteronomiese teologie. Vóór die toewending tot Jahwe wat deur die deuteronomiese hervorming tot stand gebring is, het Israel betreklike vrede gehad, maar sedert die toewending begin die onheil saampak. Dit is presies die teenoorgestelde van wat volgens die deuteronomiste se eie vergeldingsleer behoort te gebeur het, en daarom kon die worsteling met die dogma (soos bv in Ps 49, 73) en die omverwerping daarvan (soos in Job) nie uitbly nie. In hierdie tyd word die godsdiens al persoonliker (bv te sien in Jeremia en Esegiël se nadruk op die persoonlike verantwoordelikheid). Dit het duidelik geword dat die hervorming nie breë instemming gevind het nie. Jeremia het by die intrede van die katastrofe 'n belangrike bydrae tot die behoud van die Jahwisme gelewer deurdat hy betoog het dat Jahwe self die ondergang bewerk het en dus nie deur ander gode oorwin is nie.

Die derde periode in Valeton se beskrywing begin met die ballingskap. Die Joodse eie aard is veral deur die instellings van die besnydenis en die sabbat bewaar. Valeton vind by Esegiël egter reeds elemente van die latere Joodse deïsme soos deur Qohelet verteenwoordig. Nog ' $n$ kenmerk van hierdie periode is dat daar verwydering tussen God en mens begin intree, en allerlei bemiddelende figure en gepersonifieerde begrippe begin die ruimte tussen hulle vul. Ook hierdie insig het later wye instemming gevind. Valeton was nie alleen krities op die godsdienshistoriese werk van Kuenen nie, maar ook daarvan afhanklik. Op dié wyse het hy getoon dat dit moontlik is om te verskil, maar ook ten spyte daarvan te kan waardeer. Dit gaan hier om Kuenen se tese van die Priesterskrif as die na-eksiliese dokument waarin die tydgenootlike godsdiens gekodifiseer is. Hoewel Valeton nie bewus was van die feit dat Kuenen vóór K H Graf met hierdie tese gekom het nie (sien Loader 1984a: 13-17), het hy saamgestem met die tese (wat juis in Kuenen se godsdiensgeskiedenis verskyn het). Die vyfde-eeuse godsdiens, soos uitgedruk in hierdie dokument, het vol- 
gens Valeton die maatstaf vir later tye geword. Die wet het in hierdie tyd 'n drieledige karakter verkry, naamlik 'n stelsel om vreemde dinge uit te hou, om vrye toegang tot Jahwe te verhinder, en om die verhouding met God te herstel. Terwyl Esegiël die vader van die eskatologie is en Nehemia op die denkbeelde van Esegiël aan die gemeente gebou het, het Deuterojesaja met die verkondiging van 'n universele monoteïsme vorendag gekom.

Nehemia, wat volgens Valeton deur Esra opgevolg is en nie ná Esra gekom het nie, het die einde van die deuteronomistiese beweging ingelui. Hier begin die teokratiese karakter van die godsdiens oorgaan in dié van 'n hiërokrasie. Dit is teen die einde van hierdie periode waarvan die oorspronge van die Samaritaanse gemeente, die vorming van die Ou-Testamentiese kanon en die Joodse instelling van die kanon gesoek moet word.

Die laaste periode begin ongeveer 320 v C met die Griekse tydvak, toe die Jode eers onder Egiptiese en toe onder Siriese heerskappy gestaan het. Die vinnige groei van die Griekse diaspora was godsdienshistories uiters belangrik omdat die Septuaginta daaruit ontstaan het. Ná die Makkabese tyd het die breuk in die Jodedom ontstaan wat gelei het tot die ontstaan van die partye van die Fariseërs, Sadduseërs en Esseners. Die laaste ontwikkeling waaraan Valeton aandag gee, is die Palestynse soort wysheid van die Sirag-tipe en die Alexandrynse soort van die Sapientia-Salomonis-tipe (Valeton 1897: 314-325).

Met hierdie oorsig wou ek ' $n$ aanduiding gee van Valeton se belesenheid en historiese sin. Sy beskrywing van die godsdiensgeskiedenis van Israel is in baie opsigte 'modern' en vertoon die belangrikste trekke van wat vandag nog oor dié godsdiens gesê word. Die vernaamste leemte in die werk is die verwaarlosing van die plek en bydrae van die godsdiens soos vergestalt in die wysheidsliteratuur en die liriek. Die rede hiervoor is waarskynlik dat Valeton sy hele skets rondom ' $n$ 'hoofdogma' opgebou het. Hy wou nie die godsdiensgeskiedenis beskryf as die ontvouing van 'n enkele grondgedagte nie, maar die invloed van so ' $n$ benadering skemer tog hier en daar deur - soos in die pas genoemde gevalle. Daaruit blyk hoe Valeton ten spyte van die talle aanduidings dat hy bo sy tyd uitgewys het, tog nog 'n kind van sy tyd gebly het.

Sy beskrywing van die godsdiensgeskiedenis, is wel nie kwantitatief van dieselfde omvang as dié van Kuenen nie, maar die twee is wel vergelykbaar: Beide is deurdag en sistematies, beide bied ' $n$ duidelike weergawe van die gang van die godsdienstige ontwikkeling soos die outeurs dit gesien het, beide is gebaseer op die ondersoek van die 
beskikbare bronne self, beide is krities in hul hantering van die bronne. Die wesenlike verskil is dat Kuenen se aanbieding in ' $n$ rigiede evolusionistiese skema ingedwing is, terwyl Valeton s'n afgerond, maar nie strak is nie en van die ontwikkelingsgedagte in die sin van dinamiese verandering gebruik maak. Die konklusie is dat Valeton, hoewel hy in detail nie soveel virtuositeit as Kuenen gehad het nie en ook nie soveel invloed uitgeoefen het nie, 'n meer ewewigtige historiese visie op die Israelitiese godsdiens gehad het as Kuenen.

Ons beeld van Valeton se godsdienshistoriese arbeid sal nie volledig wees as ons nie ook aandag gee aan die wyse waarop hy sy insigte op grondige detailstudies gebaseer het nie. Dit kan aan die hand van talle van sy werke gedoen word, maar ons sal hier aandag gee aan ' $n$ aantal studies wat hy tussen 1881 en 1897 , toe sy twee vername godsdienshistoriese werke verskyn het, die lig laat sien het (vgl Loader 1984b: 56-61). Simon J de Vries (1968: 101), wat verskeie studies oor Nederlandse Ou-Testamentici van hierdie periode onderneem het, tipeer hierdie ondersoeke ten onregte as 'n versameling van terminologiese gegewens in verband met die Wellhausen-Kuenen-Heksateugrekonstruksie. In werklikheid gaan dit om begripstudies waarin Valeton nie alleen terminologie nie, maar ook die religieuse fenomene self nagaan. Daaruit blyk die metode waarmee hy met die tekste van die $\mathrm{Ou}$ Testament omgegaan het en met behulp waarvan hy sy godsdienshistoriese resultate verkry het.

In 'n opstel oor 'De Israëlietische Godsnaam' (Valeton 1889b: 173-221) gaan hy eers die naam jhwh, die geskiedenis en die onuitspreeklikheid daarvan na. Daarna kom die verskillende teorieë oor die oorsprong van die Jahwisme na vore. Dit gaan dus nie om terminologie nie, maar om die oorsprong van Jahwe. In die loop van die bespreking uit Valeton weer 'n gedagte wat later groot opspraak sou verwek toe die volle konsekwensies daarvan deur James Barr (1961: 107 e v) uitgewys is, naamlik dat daar onderskeid gemaak moet word tussen die betekenis van ' $n$ woord in die bewussyn van Israel en die herkoms van die woord. Soos gewoonlik in Valeton se 'hedendaagse' insigte, word die saak nie uitgewerk nie, maar hy het reeds die punt ingesien wat miskien die grootste enkele revolusie in die Ou-Testamentiese wetenskap teweeg gebring het. Daar volg 'n uitgebreide studie, met klem op Eksodus 3:14, om te toon wat Israel oor Jahwe gedink het. Die toekomstige of belofte-karakter van die naam maak dat Valeton dit (in hierdie stadium van sy loopbaan) as die eenheidsprinsipe wou gebruik by die beskrywing van die godsdiensgeskiedenis. 
Hy lê veel klem op die diversiteit van die godsdiens en die onmoontlikheid om dit alles onder een noemer te bring, maar ook op die moontlikheid dat oorbeklemtoning daarvan tot atomisering kan lei. In sy beklemtoning van Eksodus 3:14 as middelpunt, is hy nie ver van wat Walther Zimmerli (1975: 14) later daarmee sou doen nie, hoewel Valeton se gebruik daarvan in die huidige konteks (wat Jahwe vir sy volk sal wees) reeds dui op die 'gronddogma' in 'Die Israeliten'. Valeton vervolg met die verskillende tradisies oor die Godsnaam en ' $n$ uitgebreide studie van jhwh $s^{\prime} b \bar{a} \bar{o}$. Die tekortkoming van hierdie studie lê nie soseer in wat Valeton geskryf het nie, maar in die feit dat hy net twee van die talle Godsname ondersoek het.

Aan die begin van dieselfde band kom nog 'n grondige studie van Valeton (1889a: 1-38) voor oor 'Het kennen van God volgens de boeken des Ouden Verbonds'. Hierdie opstel bevat geen polemiek nie en gee slegs die resultate weer van 'n gedetailleerde studie van die fenomeen 'Godskennis' en die kompleks van voorstellinge wat in die Ou Testament daarmee geassosieer word. Deel van hierdie studie is ' $n$ semantiese ondersoek na die werkwoord $j d^{c}$ in die Ou Testament. Hoewel daar nog baie onduidelikhede voorkom, kan ons hierdie aspek van die studie ook as baanbrekend beskou. Valeton het hier begin werk met die idee van betekeniskomponente, wat eers relatief onlangs in die Amerikaanse 'componential analysis' standaardpraktyk geword het. Valeton het nooit die term 'component' gebruik nie, maar wel 'bestanddeel' (Valeton 1889a: 4). Die idee is egter dieselfde. Hy het die werkwoord $j d^{c}$ beskou as sowel 'n statiewe as 'n ingressiewe werkwoord en twee betekenisaspekte van die werkwoord $j d^{c}$ in die uitdrukking 'God ken' gevind: 'weten hoedanig hij is' en 'erkennen'. Sy veronderstelling dat ons hier nie met twee betekenisse nie, maar met twee komponente van een betekenis te doen het en dat beide oral teenwoordig is waar die werkwoord voorkom, sal vandag nie meer aanvaar word nie. Die idee dat 'ken' bestaan uit die komponente 'intellektueel' en 'oorgang in die kennende staat' is egter duidelik teenwoordig.

Nie alleen die betekenis van die woord nie, maar die godsdienshistoriese fenomeen word bestudeer. Dit blyk daaruit dat ook die voorwerpe van die kennis (Jahwe se persoon, eienskappe, dade en apposisies) en die gronde daarvan onder die loep kom. Die hele idee van Godskennis berus volgens Valeton op openbaring. Israel abstraheer sy Godskennis nie uit die natuurlike nie, maar hoor God mede in die natuurlike spreek. Hierdie Godskennis was nie 'n abstrakte Godsbegrip nie, maar dit wat die Israeliete in werklikheid van God gemerk 
het. Verskillende teengestelde opvattinge van God, byvoorbeeld beroulik en onberoulik (Valeton 1889a: 26), toon dat ons nie met 'n sluitende begrip te doen het nie, maar met verskillende ervaarde verhoudings tot Hom as persoon. Die ken-relasie tussen mens en God kom veral tot uiting in die beheersing van die lewe deur Jahwe en het dus 'n sedelike karakter.

Hoewel ons hier met 'n detailondersoek te doen het, word die basiese insigte van Valeton se etiese teologie onmiskenbaar daardeur onderbou (openbaring, relasie, geen abstrakte begrip nie, sedelike karakter). Dit kan dus moeilik as ' $n$ voorbereidende studie vir die 1897werk bestempel word, en moet eerder beskou word as ' $n$ bevestiging van die kern van Valeton se hele teologie wat reeds gevorm was toe hy hierdie een geskryf het (1888).

'n Paar jaar ná hierdie studies het Valeton (1891: 101-156) 'n soortgelyke ondersoek gepubliseer oor 'Beteekenis en gebruik van het woord Thorâ in het Oude Testament'. Reeds die titel is belangwekkend omdat dit ' $n$ onderskeiding aandui tussen betekenis en gebruik van woorde. Valeton se studie, wat inderdaad langs hierdie lyne werk, begin met aantekeninge oor betekenis en afleiding van die woord tōrā en gaan dan voort deur te wys op die addisionele assosiasies wat ontstaan deur die gebruik daarvan in spesifieke tekste, byvoorbeeld die verband met die priesterskap, regspraak, melaatsheid, urim en tummin en so aan. Dit is dus 'n godsdienshistoriese analise waarin sekere taalkundige elemente voorkom. Die konklusie lui dat daar naas die priesterlike tōrā of onderwysing (vir uitwendige handelinge) ook 'n profetiese tōrā (vir die ganse bestaan) is, dat daar meer as een tōrā in die Pentateug is, en dat die törā 'n objektiewe grootheid word wat eerder uitgelê as uitgereik moet word. Vervolgens kom 'n studie van tōrā in die D- en Pbronne, waaruit blyk dat 'n ou priesterlike tōrã naas 'n skriftelike tōrā bestaan het (Valeton 1891: 126-135). Op verskillende plekke (veral in Jeremia) vind Valeton die betekenis 'geopenbaarde wil' van Jahwe en nog nie 'wetboek' nie, terwyl die oudste betekenis 'voorlichting' in die Spreukeboek teruggevind kan word. Hierdie gegewens toon dat Valeton drie betekenisse vir die woord onderskei het (voorligting, eis, wetboek) en dan 'n hele reeks bykomende assosiasies onderskei wat te doen het met die gebruik van dié betekenisse (bv priesterlik, profeties, verskillende soorte wette en versamelings, ens). Valeton het nie hierdie insig uitgewerk nie, maar hy moet krediet kry vir 'n belangrike onderskeiding wat hy op onafhanklike en selfstandige wyse gemaak het. In die onderhawige geval is dit selfs wesenlik omdat die kategorieë bete- 
kenis en gebruik die grondslag van die hele studie vorm. Dit is ook vir 'n godsdienshistoriese studie soos hierdie belangrik omdat juis die godsdienstige verskynsels wat in 'n fenomenologiese ondersoek onder die vergrootglas kom, op die terrein van die gebruik eerder as dié van die betekenis gevind word.

Gedurende die volgende twee jaar het daar van Valeton drie agtereenvolgende artikels in Duits oor die verbond verskyn (Valeton 1892a: 1-22, 1892b: 224-260, 1893: 245-279). Aldrie is van soortgelyke aard as dié wat ons so pas behandel het, waar dus nagegaan word hoe die verbondsvoorstelling by verskillende outeurs/dokumente daar uitsien. So het Valeton weer met behulp van ondersoeke van literêre aard en met inagneming van taalkundige gegewens probeer vasstel watter religieuse motiewe in die verskillende strata van Israel se religieuse dokumente rondom die verbondsgedagte ' $n$ rol speel. Sy ondersoek van byna ' $n$ honderd bladsye is buitengewoon grondig. Dit wys uit hoe die drie momente van die Abrahamsverbond (nageslag, seën wees, land) in die Priesterskrif uitgewerk word. In die middelste van die drie artikels kom daar selfs ' $n$ interessante ongenoeë van Valeton (1892b: 248-249) met die voorstelling van ' $n$ 'Grundbedeutung' voor. Hy vind dit moeilik om 'n grondbetekenis vir $b^{\text {'rît }}$ vol te hou as die term soms 'Zusage' en soms 'Gesetz' kan beteken - wat weer ' $n$ illustrasie is van hoe Valeton insig begin toon het in probleme wat lank ná sy tyd eers dominant sou word. In die laaste bydrae kom Valeton tot die konklusie dat, sover dit die profete en die ketubim aangaan, die eintlike religieuse gebruik van $b^{\prime}$ rit eers sedert die Deuteronomies-Jeremiaanse tyd voorkom. Daar is nooit sprake van gelyke verbondsgenote nie en klem word gereeld gelê op die beloftes sowel as die verpligtinge. Vir Valeton was die verbond in wese 'n saak van Jahwe se trou (hesed).

Valeton se godsdienshistoriese arbeid wys in verskeie opsigte bo sy eie tyd uit. Sowel in negatiewe opsig (bv die weerlegging van die positiwistiese beskrywing van Israel se godsdiensgeskiedenis) as in positiewe opsig (bv die verskeidenheid van insigte wat dekades later deur andere prominensie gekry het) het Valeton bo sy eie tyd uitgestyg. Veral sy aandrang dat teologiese arbeid aan die Ou Testament nie 'n godsdienshistoriese basis kan ontbeer nie en die grondslag waarop hierdie oordeel berus, naamlik die onderskeid tussen geloofs- en wetenskaplike kennis, is van blywende betekenis.

Dit is hierdie insigte wat op professor Van Selms ingewerk het en deur hom aan die Suid-Afrikaanse teologiese toneel bemiddel is. Van Selms, wat self as godsdienshistorikus gepromoveer het, het die in- 
vloed van die etiese tradisie volgens homself al in sy ouerhuis ondergaan, maar die eintlike impak van die benadering waaraan ons aandag gegee het, het via sy leermeesters, H Th Obbink (1869-1947) en F M Th de Liagre Böhl (1882-1976), tot hom gekom. Eersgenoemde was sy promotor in die godsdienswetenskap en laasgenoemde het tot sy vorming in die Semitistiek bygedra. Beide was van die jongere generasie onder Valeton se medestanders en dus direkte skakels tussen hom en Van Selms. Dit is nie onbelangrik nie dat Van Selms kort voor sy dood hierdie tradisieketting sowel as sy eie wesenlike ooreenstemming met die benadering van Valeton bevestig het (4 April 1984). Van Selms het baie ooreenkomste met Valeton gehad - prinsipieel sowel as ten opsigte van briljansie en virtuose leierskap. Hy was nie 'n klakkelose dissipel van Valeton nie (hy het talle geskrifte van Valeton nie eens geken nie), maar het in dieselfde idioom gedink en op dieselfde grondslag gewerk. As hierdie gees van Valeton in Suid-Afrika herontdek word, sal dit alleen 'n bewuswording wees van die wortels van die geestesgoedere wat Van Selms ons kom leer het.

\section{Literatuurverwysings}

BARR, J 1961. The semantics of biblical language. London: Oxford University Press.

GUNNING, JH [1940]. Herinneringen uit mijn leven. Amsterdam: Spruyt.

KUENEN, A 1869. De godsdienst van lsraël tot den ondergang van den loodschen staat 1. Haarlem: Kruseman.

LOADER, JA 1984a. The exilic period in Abraham Kuenen's account of Israelite religion. ZAW 96, 3-22.

LOADER, JA 1984b. Die etiese Ou-Testamentici in Nederland tussen 1870 en 1914. D Thproefskrif, Pretoria: UNISA.

LOADER, JA 1985a. The writings of Professor Adrianus van Selms. INWSL 14.

LOADER, JA 1985b. The concept of revelation in Dutch ethical theology: its implications for Old Testament scholarship. OTE 3.

VALETON, JJP 1879. Pro Domo. St 5, 207-216.

VALETON, JJP 1881. Bijdragen tot de kennis en waardering van den Israëlitischen godsdienst. St 7, 1-27, 81-120.

VALETON, JJP 1889a. Het kennen van God volgens de boeken des Ouden Verbonds. Th St 7, 1-38.

VALETON, JJP 1889b. De Israëlitische Godsnaam. Th St 7, 173-221.

VALETON, JJP 1891. Beteekenis en gebruik van het woord thorâ. Th St 9, 101-156.

VALETON, JJP 1892a. Bedeutung und Stellung des Wortes b'rit im Priestercodex. ZAW 12, $1-22$.

VALETON, JJP 1892b. Das Wort berit in den jehovistischen und deuteronomischen Stücken des Hexateuchs, sowie in den verwandten historischen Büchern. ZAW 12, $244-260$.

VALETON, JJP 1893. Dat Wort $b^{e}$ rit bei den Propheten und in den Ketubim - Resultat. ZAW 13, 245-279. 
VALETON, JJP 1895. Christus en het Oude Testament. Met een voor-en naschrift naar aanleiding van dr Hoedemaker's 'Als verleiders en nochtans waarachtigen'. Nijmegen: Ten Hoet.

VALETON, JJP 1897. Die Israeliten, in Saussaye, P D Chantepie de la, Lehrbuch der Religionsgeschichte. 2. Aufl. Freiburg: Mohr.

VALETON, JJP 1898. De veronderstelling der theologie. Utrecht: Van Druten.

VRIES, SJ DE 1968. Bible and theology in the Netherlands. Dutch Old Testament criticism under modernist and conservative auspices - 1850 to World War 1. Wageningen: Veenman.

ZIMMERLI, W 1975. Grundriss der alttestamentlichen Theologie. 2. Aufl. Stuttgart: Kohlhammer. 